sulted in noticeable injury to the seed, showing that this substance as sold is of very unequal quality and apparently of unlike composition.

In reply to questions Mr. Forbes stated that the rows of corn in the field were about a quarter of a mile long; that the seed corn had been specially selected for the purpose and that, in the strips where the lemon oil was used, at a cost of about ten cents per acre, the ants were present between the rows, but very few aphids could be found.

Mr. Bishopp stated that he had tried repellants against the cotton boll weevil, including lemon, cinnamon, tar and clove oil. The odor of the latter was most persistent, but where it was used the plants showed greatest injury.

Mr. Forbes remarked that when lemon oil was introduced into artificial ants' nests it seemed to set them crazy, as they acted in a very confused and abnormal manner, even neglecting and deserting their young.

Mr. Taylor presented a paper:

\title{
LIFE HISTORY NOTES AND CONTROL OF THE GREEN PEACH APHIS, MYZUS PERSICAE
}

By E. P. Taylor, Mountain Grove, Mo.

The aim of this paper is to add a few new observations upon a very old insect. It was in 1761 , nearly a century and a half ago, that Sulzer first described this pest in Europe. It has been mentioned in most works upon the Aphididæ as well as in treatises upon general entomology published in this country for many years, and has long since been included in the lists of insects injurious to the peach in the United States and Canada. Like many of our common insect enemies, however, there have been and are yet many points concerning it unrecorded.

During the past two years or more this insect has become in parts of the country a pest of more than passing importance. The peach growers of Western Colorado have suffered loss from it; from its heavy infestation of the leaves of the trees in the spring, causing them to curl and drop prematurely to the ground, and from the withering and subsequent dropping of the buds and forming peaches also infested by the aphides at this time. It is probable that in many parts of the country this plant louse has not yet appeared in such injurious numbers as to infest and destroy a portion of the erop itself as it has in Western Colorado, but the insect is of interest since it is known to 
occur in nearly all portions of the United States where peaches are grown.

Our interest is also increased when we realize to what extent it has probably been confused with other species of the sub-family Aphididæ, and when we understand the factors which have led to this confusion.

My first notice of the insect as an economic pest in Colorado was at Grand Junction on April 13th, 1906, and brief mention was made of it in Bulletin No. 119, Colorado Agricultural Experiment Station. Its identity was then unknown to me and before undertaking any control experiments material was sent to Prof. C. P. Gillette, our best authority on the Aphididæ of that section. Samples of the material were also sent to Mr. Theo. Pergande of the United States Department of Agriculture, who gave to the insect the name Rhopalosiphum dianthi Schrank, as did Professor Gillette on first looking over the material. The latter, after further study of the insect and literature, concluded that the name Myzus persicae Sulzer should be applied to it. In this study of it certain matters of importance regarding the synonomy of the insect were brought out and I shall quote from a letter of Professor Gillette dated November 7th, 1907: "Let me change my opinion in regard to what this louse ought to be called. I decided to call it diantha Koch, but our species seems to be the persicae described by Sulzer in 1761 and which is described and figured by Buckton in his work on British Aphididæ, vol. 1, page 173. Buckton's figures correspond remarkably well with the louse that we have been working on here. I also believe that Rhopalosiphum solani Thomas, $R$. dianthi Schrank, and Myzus achyrantes Monell are synonyms of this species. All of the returned migrants that we have found upon plum, peach and cherry during the fall have had cornicles that were slightly swollen or clavate in form. The first winged forms in the spring that appear on these same trees seem exactly like the fall winged form, except that the cornicles are not at all swollen. I was greatly puzzled over this fact last spring and determined to watch very closely this fall to determine whether or not the form with swollen cornicles would again appear upon the peach and plum trees. For the past six weeks these migrants with swollen cornicles have been gathering upon these trees and depositing the oviparous form which becomes pink or salmon in color as it grows toward maturity. Since the middle of July we have been taking this louse upon a large variety of plants and in all cases we have found the cornicles swollen. This seems to account for the louse being called a Rhopalosiphum when described from the summer and fall form and Myzus when described from the early spring form before it leaves the peach, plum and cherry 
tree. The specimens you sent April 30 and May 7 from peach all have cornicles cylindrical. The fall migrants and the specimens sent from tomato and turnips early in the summer all have clavate cornicles in the winged form. *** The distinguishing character of this species for the winged individuals seem to be: Antenna longer than the body upon pronounced frontal tubereles which are quite approximate, second joint of antenna moderately gibbus, third joint with sensoria on the ventral side only and a large dark patch upon the dorsum of the abdomen anterior to the cornicles, and during the late part of the season the cornicle moderately clavate in the winged forms."

A point brought out by the foregoing is that the large per cent. of the descriptions of this and related species were made from specimens taken in the fall. I have recently had an opportunity to go over with Mr. J. T. Monell of St. Louis some accession records of collections of this species made during a period of about thirty years and the majority were found to have been made in the fall. In fact but a single exception to this was found, which was in the case of the species given by Mr. Pergande as Aphis persicae Sulz., and taken by him in St. Louis in May, 1879.

I have found in Western Colorado the eggs or stem-mothers of Myzus persicae Sulz. upon peach and plum and the lice have been found in that state at different times upon peach, nectarine, plum, prune, cherry, choke-cherry, sand-cherry and more rarely upon pear, apple, crab-apple, willow and cultivated rose. Also the following herbaceous plants have been found as host plants at some seasons of the year: Turnip, rape, cabbage, tomato, potato, false-mallow (Malvastrum sp.) yellow-dock, red-root (Amarantus sp.) mustard, shepherd's-purse, snap-dragon, carnation, rhubarb and egg-plant. In not every instance upon the plants given were the pink or salmon-colored lice present, although the collections were sometimes made in the spring or fall when this form would have been expected. This leaves perhaps a possibility of other species being mistaken for this one unless the kind of food plant had affected the coloration of the louse. Mr. Monell recently showed me two samples of what seemed to be this species taken by him November 2-4, 1907, at Shaw's Garden, St. Louis, one from cabbage and one from peach. Both cases showed the winged forms with slightly dilate cornicles and otherwise appearing the same, but none of the lice upon the cabbage showed the salmon color, though they were abundant upon the peach leaves at that time.

In this paper I have designated this insect as the green peach-aphis, to distinguish it from the black peach-aphis, with which it is sometimes confused. It is very different from the latter, however, which has in 
the matured insects a shining black body and young of a reddishbrown. The latter, too, is known to sometimes infest the roots of the peach, while the green peach-aphis, so far as is known, occurs only above the ground.

If very abundant, the lice will be seen collecting thickly about the buds long before they open. If fewer in number, they may escape observation until the leaves are attacked and curled. In the spring of 1906 the writer noticed the serious bud infestation first on April 13. In 1907, eggs were found hatching at Grand Junction as early as February 16 , owing to the unusually open winter and early spring. The eggs, small, oval and shining black, resemble very much the eggs of the green apple-aphis. They are deposited in the fall upon the twigs of peach or sometimes the plum or cherry and are tucked away under the bud or upon rough places along the bark, usually somewhere near the tips of the twig. They are not placed in such masses as the eggs of the green apple-aphis and it usually requires rather close searching to discover them. I found them deposited this fall as early as October 24 at St. Louis, and Professor Gillette reported them being laid freely at Ft. Collins, Colorado, as early as November 5 .

Soon after hatching the lice crawl to some nearby leaf or fruit bud and insert their beaks into the more tender portion. At the time the first lice are hatched, the buds, though considerably swollen, are still protected by thick bud-scales which are more tender near the apex. The stem-mothers, when first hatched, are of a dark green color, with almost black appendages, and in length not more than 2-100 of an inch. As the inner and redder bud-scales are pushed out, these also become covered with stem-mothers, which after their first moulting of skins begin to assume shades of pink or salmon. These shades will be first noticed along the lateral margins of the body. As the stemmother increases in size and continues to moult, this color becomes more prominent. Examined carefully, these dorsal abdominal markings will be found to consist of light terra-cotta or even maroon colors upon an apple green, the combination giving a salmon or pink in general effect. All stem-mothers do not take on this typical shade, but remain green throughout their lives and those which do assume the salmon color often fade back into almost a green toward the close of the period of their existence.

The stem-mothers blend very closely with the colors of the buds and blossoms and are therefore not easily seen. At the time of the birth of their first young, they measure about 8-100 of an inch in length. The young, which are born living, are at first much paler green in color than were the stem-mothers when first hatched. The apterous in- 
dividuals of all generations appearing after the spring stem-mother remain greenish in color throughout the season up to when the sexual females are found upon the leaves in the fall. These deposit the overwintering eggs and the lice are also of a salmon or pink shade, very much like the stem-mothers of the spring.

I have counted as many as a score of the stem-mothers in the spring clustered over the surface of a single unopen bud. When the buds break into bloom, these stem-mothers and their progeny crowd within, attacking petals and inner walls of the corolla as well as the stamens, style and ovary. The bloom is distorted, becomes withered and finally falls. In other cases the clusters of lice form later about the peaches, when about the size of peas, and by sucking away the sap cause them to also fall from the trees. About this time the lice will also begin to infest the leaves, curling them tightly, by infesting their under surfaces, and when severely attacked all parts of the leaf-blade will be completely covered. After the second molt of the stem-mothers, minute drops of honey-dew may be seen to form at the tip of the insects's body and be thrown away with a quick movement. This honey-dew may appear before the buds open as moist, sticky areas upon the twig above the louse. Later in the spring, the leaves in badly infested terminal clusters become completely coated with this secretion and attract numbers of ants, flies and other insects.

The infested leaves become thickened and pitted from beneath, turning red in spots and finally falling away. About the middle of May, 1907, many peach trees in Western Colorado were almost completely stripped of their foliage and it was feared by many growers that some would never revive.

Winged lice developed among individuals of the first generation following the spring stem-mothers and were seen in the orchards as early as April 13, 1907. They appeared as a rule first upon leaves greatly over-crowded by the wingless lice and soon after developing wings, spread to other leaves and trees to start new colonies. The proportion of winged ones increased as the season advanced. About the middle of May last year at Grand Junction, when the leaves of the trees had become heavily infested, not only winged but the wingless lice were seen to commence migration in great numbers from peach trees. By the last of May or the first days of June, scarcely a single one could be found upon them. It was indeed interesting to witness this phenomenal dispersion of plant lice. Each seemed anxious to forsake the peach leaves before its neighbor. Some days the air in badly infested peach orchards would be filled with flying aphides. The ground in such orchards would be thickly scattered with crawling, 
wingless aphides. In one instance, trunk-bands of the sticky substance known as "Tree Tanglefoot" had been placed upon apple trees in order to eatch the erawling woolly aphides. These apple trees were adjoining an orchard of peach and when the crawling lice from the peaches started up the trunks of the apple they were caught in such numbers that the lower borders of the bands were green with a mass of their bodies. The peach trees, now deserted by their parasites, the aphides, soon began to form new leaves and within a few weeks were once more in heavy foliage. The wingless migrating aphides evidently perished in great numbers upon the ground before reaching other food plants; some winged ones safely reached other plants at a distance, where they established new colonies and multiplied until the winged migrants returned again to the peach in the fall.

Life history records for the early spring generations were secured in the breeding cages. Stem-mothers were kept alive from twenty-three to twenty-nine days from hatching. About eight days passed from hatching to the first molt, four or five days from the first to the second molt and about the same time from the second to the third. From fifteen to seventeen days were passed by the stem-mother from hatching to the birth of the first young. This record was secured by confining single stem-mothers in cages alone, and thus demonstrating them to be parthenogenetic. The first young were born about the time of the third molting by the stem-mother. The maximum number of young secured from one stem-mother in the cages was twenty-six.

The first young of the second generation from the eggs were seen born in the orchard at Palisade on March 14, 1907, though some were secured in cages as early as March 4 . From the birth of the second generation to the first molt was from four to five days and from their birth to their becoming equipped with wings was on an average of from eleven to sixteen days. This second generation usually bore the first of the third generation about twelve to seventeen days from their birth and at about the time the first winged lice appeared. Only a portion of the second generation of lice developed wings. From twenty-eight to thirty-three days seemed about the length of life from birth to death of a second generation individual.

The third generation of agamic aphides were found in the orchard at Grand Junction last season on March 24. These lice are a trifle smaller at birth than the generation born by the stem-mothers. It will be seen that as many as thirteen generations of the green peach aphis may be produced through a single season if the same rate of development is kept up through the summer to the time when eggs are again deposited in the fall. 
The food plants which carry the species through its summer generation appear to be of great variety, as shown by the list already mentioned. So few lice are to be found, however, upon these plants during the summer in comparison with the countless numbers which are produced in the peach orchards in the spring that it seems very probable that other plants will also be found harboring it through the summer months.

In the Grand Valley peach orchards the first returning migrants were noticed about the middle of September, when I found them collecting upon the dorsal side of the leaves, principally along the midrib and veins, though they were not altogether restricted to these points. No early examinations of peach orchards were made in Missouri this fall, but on October 24, oviparous females were found depositing their eggs along the Mississippi and under date of November 5 Professor Gillette wrote me from Colorado that the eggs were being deposited upon peach, plum and cherry, though many of the winged and wingless viviparous females were still living upon many outdoor plants that had not entirely lost their foliage. The male insects are winged and appear in Colorado from about the middle of September to when they are killed by the cold nights. In Missouri, near St. Louis many eggs were still being freshly deposited in peach orchards as late as November 16.

Parasites and predaceous enemies rendered the orchardists of western Colorado much service in destroying great numbers of these insects last summer. Among these were the larvae of syrphus flies and lace-wings, and the larvae and adults of lady beetles. A small hymenopterous parasite was seen to infest the lice and a Thomisid spider identified by Mr. Banks as Thisumena lepida Thorell was observed to be of service. Sparrows, eanaries, orioles and other birds were also of economic value.

Experiments by the writer towards the control of this pest were undertaken against it only so far as it affected the peach. In the commercial orchards of Western Colorado its only injury has been caused to this fruit.

The remarkable power peach trees have of reviving after being almost completely defoliated by these lice makes the insect somewhat less formidable. However trees so completely stripped of their foliage and devitalized as they are in some cases are retarded in both the development of the tree and fruit. From a practical standpoint the destruction of the lice which may infest the fruit buds, blossoms or newly formed peaches may be considered of the greatest consequence to the grower. 
We find insecticides recommended against this insect in the works of Dr. Cyrus Thomas, formerly state entomologist of Illinois, and published in the transactions of the Illinois State Horticultural Society for 1876. Townsend observed the insect in New Mexico upon peaches and recommended contact sprays against it in Bulletin No. 3, New Mexico Agricultural Experiment Station, June, 1891. Saunders, Weed and many others have also suggested treatments. Washes of strong soap-suds, tobacco-water, kerosene emulsion and many other contact insecticides commonly used against sucking insects were advised.

From the experience of the writer, it has seemed that time and manner of application has had much to do with successful results. I have conducted experimental spraying against this insect near St. Louis, Missouri, in a peach orchard of about one hundred and thirty medium aged trees, the spraying being done on November 16 . In Colorado a commercial peach orchard at Palisade was carefully selected and treated on March 16, 1907, when the stem-mothers were thickly covering the outside of the peach bud. The peach buds were swollen and ready to burst into bloom. The first new-born of the second generation were appearing, but neither these tiny green lice nor the larger pink-bodied stem-mothers had gained entrance into the blossoms beyond the reach of contact sprays. At that date practically all of the eggs had been hatched.

An orchard of about one hundred peach trees at Grand Junction was chosen in which no spraying was given up to April 16, when portions were given a thorough treatment with different contact sprays. At the time this spraying was done, the leaves of the trees were badly infested and the lice concealed to a large extent within the folds.

In both of the orchards a thorough spraying was given, but it was plainly apparent that the orchard first mentioned-the one sprayed late in the spring, but immediately preceding the opening of the buds - was the one in which the better results were secured. In the one sprayed after the leaves had become curled, it was found almost impossible to reach the bodies of the lice. Some of course were killed when a strong stream of spray was forced into the branches under a high pressure, but it was manifestly too late to expect the best results.

Among the most promising insecticides used in the experiments and by orchardists who sprayed last spring for this pest in Colorado were kerosene emulsion, containing $5 \%$ oil, Scalecide diluted 1 part to 20 parts cold water, tobacco decoction made by steeping for an hour 1 pound of leaf tobacco or 2 pounds strong tobaceo dust or stems in 
4 gallons of water. "The Black Leaf Extract of Tobacco" proved equally successful when used at the rate of 1 gallon to 65 gallons of cold water.

If the kerosene emulsion or other commercial oil emulsions are used, it should be with the usual precautions. Complete emulsification and known percentage of oil are essential. The above strengths of emulsion gave no injury used in the manner described. No practical benefit was secured, so far as the green peach aphis is concerned, from the use of orchard-boiled or commercial lime-sulphur washes, applied late in the spring just before the buds open. All spring prunings of the peach twigs should be gathered up and burned to prevent the aphis eggs harbored upon them from hatching and the lice crawling back upon the tree.

[Mr. Headlee's paper on Diabrotica vittata, together with the discussion thereupon, has been held till the next issue, owing to delay in submitting the manuscript.-E. P. F.]

The following paper was presented:

\title{
A KEY SUGGESTED FOR THE CLASSIFICATION OF EN- TOMOLOGICAL RECORDS
}

\author{
By W. E. Hinds and F. C. Bishopp.
}

Object and application of key. This key is designed to facilitate the arrangement of entomological notes, materials, etc. It is not to be used as are guide cards, but all cards belonging in the key are placed together in front of the note file to show the general plan of arrangement of the notes which follow. Thus one key serves for the entire note system and no repetition is needed for the various species regarding which notes are made.

It is not at all necessary that all notes to be classified according to this key should be prepared in any particular form or kept together in one place. In fact, the key may be applied almost equally well to any notes except those in bound books. No argument is needed as to the many advantages of the modern eard system over the old bound note book system. The size of cards to be used is a matter for personal choice and the only argument for uniformity is that of convenience in filing and handling the notes. In the Cotton Boll Weevil investigation a four by six inch card was found to be most convenient for field notes and therefore adopted for practically all records of the investigation. The cards were prepared by the printer in the 


\section{$2 \mathrm{BHL}$ Biodiversity Heritage Library}

Taylor, E. P. 1908. "Life history notes and control of the green peach aphis, Myzus persicae." Journal of economic entomology 1(2), 83-91. https://doi.org/10.1093/jee/1.2.83.

View This Item Online: https://www.biodiversitylibrary.org/item/37189

DOI: https://doi.org/10.1093/jee/1.2.83

Permalink: https://www.biodiversitylibrary.org/partpdf/325832

\section{Holding Institution}

New York Botanical Garden, LuEsther T. Mertz Library

\section{Sponsored by}

The LuEsther T Mertz Library, the New York Botanical Garden

\section{Copyright \& Reuse}

Copyright Status: NOT_IN_COPYRIGHT

This document was created from content at the Biodiversity Heritage Library, the world's largest open access digital library for biodiversity literature and archives. Visit BHL at https://www.biodiversitylibrary.org. 